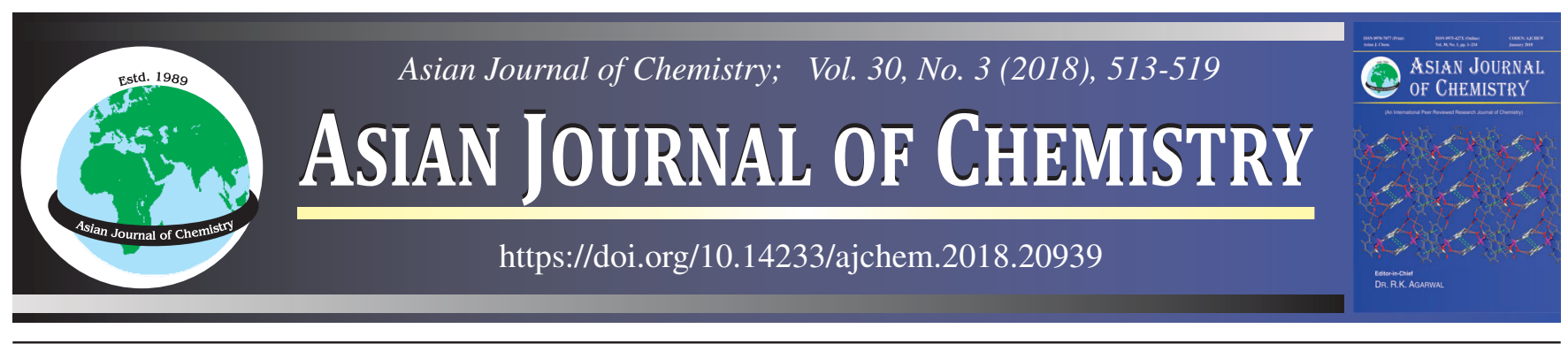

\title{
Gloriosa superba Linn. Extract as Eco-friendly Inhibitor for Mild Steel in Acid Medium: A Comparative Study
}

\author{
P.R. SivaKumar and A.P. SRIKANTH*
}

PG \& Research Department of Chemistry, Government Arts College (Autonomous), Coimbatore-641 018, India

*Corresponding author: E-mail: apsrikanth8@gmail.com

\begin{abstract}
The comparative studies of various parts of the plant Gloriosa superba Linn. extract (leaves, flowers, stems, tubers) were carried out to investigate the corrosion protection efficiency on the corrosion of mild steel in $1 \mathrm{~N} \mathrm{HCl}$ medium by using mass loss method, polarization measurements and electrochemical impedance spectroscopy at room temperature. Polarization measurements showed that the studied extract acts as mixed type inhibitor with significant reduction of cathodic and anodic current densities. Organic moieties present in the extract are found responsible for effective performance of inhibitor which is well supported by FTIR studies. On comparison, optimum inhibition efficiency was found in Gloriosa superba Linn. stem extracts with $99.80 \%$ at 15 ppm concentration. The nature of protective film formed on the mild steel surface has been confirmed by SEM analysis. The surface coverage values fits well to the Temkin adsorption isotherm.
\end{abstract}

Keywords: Gloriosa superba Linn., Corrosion, Electrochemical impedance spectroscopy.

L

\section{INTRODUCTION}

Corrosion is a common problem for several metals. Once corrosion initiates, it propagates rapidly, most dangerous is the loss of strength by corrosion, but it can be considerably reduced using various effects have been made corrosion control and prevention. Our modern societies and resulting losses each year are in the hundreds of billion U.S. dollars. The annual corrosion cost ranged from approximately 1-5\% of the Gross National Product (GNP) of each nation. Very popular and recent trend was used as green or eco-friendly inhibitor, is one of best practical method to protect/reducing corrosion attack [1-5]. More researchers have been reported for synthetic organics [6-10], polymer [11-17], heterocyclic compounds [18-25] plants extract [26-35] and various parts like leaf, flowers, seeds, fruits [36-39] as corrosion inhibitor for mild steel, aluminium, carbon steel, zinc, copper and alloys in various medium. The present work is designed as a contribution to the growing interest on environmentally benign corrosion inhibitory study to cheap, environmentally safe, less toxic and easily available substance and simple procedure [40-48]. In this study, the extracts of same medicinal plants but various parts like leaves, stems, tubers and flowers were used to investigate the corrosion protection efficiency on the corrosion of mild steel in $1 \mathrm{~N} \mathrm{HCl}$ medium.

\section{EXPERIMENTAL}

Preparation of the specimen: The composition (\%) of mild steel used in this study was $\mathrm{Mn}-0.169, \mathrm{Mg}-0.016, \mathrm{C}-$ 0.030, Cr- 0.029, P- 0.031, S - 0.029, Ni- 0.030, Cu- 0.017, Si- 0.015 and the remainder Fe of dimension $4 \mathrm{~cm} \times 2 \mathrm{~cm} \times$ $0.1 \mathrm{~cm}$ were policed to a mirror finished with the emery sheet of various grade and degreased with acetone before analysis.

Inhibitor preparation: Freshly collected aerial parts of the medicinal plants Gloriosa superba Linn. leaves, stems, tubers and flowers were dried in room temperature and ground into fine powder. $10 \mathrm{~g}$ of the fine particles was added in 150 $\mathrm{mL}$ di-ionized water and kept overnight. The aqueous solution was filtered and volume was made up to $250 \mathrm{~mL}$.

Mass loss method: Mild steel strips were immersed in $200 \mathrm{~mL}$ of $1 \mathrm{~N} \mathrm{HCl}$ acid with and without of different concentrations of the inhibitors. A $3 \mathrm{~mm}$ hole was drilled at the center for suspension for the weight loss coupons. The immersed (before and after) mild steel surface was weighed and inhibition efficiency $(\%)$ was calculated as follows:

$$
\text { Inhibition efficiency }(\%)=\frac{\mathrm{W}_{0}-\mathrm{W}_{\mathrm{i}}}{\mathrm{W}_{0}} \times 100
$$

$\mathrm{W}_{0}$ and $\mathrm{W}_{\mathrm{i}}$ are the weight loss with and without of the inhibitor.

Electrochemical methods: The polarization measurements were carried out in an electrochemical cell with a three elec- 
trode cell set up was used. Mild steel $\left(1 \mathrm{~cm}^{2}\right)$ was used as a working electrode; Pt electrode was used as counter electrode and a saturated calomel electrode as reference electrode. The electrode setup was fully and separately immersed in the acid solution for approximately $30 \mathrm{~min}$ to reach open circuit potential $(\mathrm{OCP})$ was attained. Anodic and cathodic polarization curves were obtained from $-0.5 \mathrm{mV}$ to $+2 \mathrm{mV}$ at a scan rate of $1 \mathrm{mV} \mathrm{s}^{-1}$.

$$
\text { Inhibition efficiency }(\%)=\frac{I_{\text {corr }}-I_{\text {corr }}^{*}}{I_{\text {corr }}} \times 100
$$

where, $\mathrm{I}_{\text {corr }}$ and $\mathrm{I}^{*}$ corr are corrosion current without and with the inhibitors.

Electrochemical impedance method (EIS): The same three electrode cell assembly was used to carry out the Electrochemical impedance studies. A plot of Z'versus Z" was made. The double layer capacitance $\left(\mathrm{C}_{\mathrm{dl}}\right)$ was determined using formula:

$$
\mathrm{C}_{\mathrm{dl}}=\frac{1}{2 \pi} \mathrm{f}_{\max } \mathrm{R}_{\mathrm{ct}}
$$

where, $R_{c t}$ is charge transfer resistance and $C_{d l}$ is double layer capacitance.

\section{RESULTS AND DISCUSSION}

Mass loss method: The weight loss process is undoubtedly the most commonly used method of primary calculation. The weight loss data are listed in Table-1. It was noted from the table that as the concentrations of the inhibitor increases the weight loss as well as corrosion rate are decreases and higher inhibition efficiency was found ( $99.80 \%$ for stems) at $15 \mathrm{ppm}$. This examined at the optimum concentration (15 ppm) of all four inhibitors and the sequence of the inhibition efficiency was found to be Gloriosa superba Linn. stems > leaves $>$ tubers $>$ flowers.

TABLE-1

PERCENTAGE OF CORROSION RATE (CR) AND INHIBITION EFFICIENCY (IE \%) AT DIFFERENT CONCENTRATION OF

\begin{tabular}{|c|c|c|c|c|}
\hline $\begin{array}{c}\text { Parts of } \\
\text { GSL plant }\end{array}$ & $\begin{array}{c}\text { Conc. of the } \\
\text { extract (ppm) }\end{array}$ & $\begin{array}{l}\text { Weight } \\
\text { loss (g) }\end{array}$ & $\begin{array}{c}\text { Corrosion } \\
\text { rate (mmpy) }\end{array}$ & $\mathrm{IE}(\%)$ \\
\hline \multirow{5}{*}{ Leaves } & Blank & 0.1107 & 64.258 & - \\
\hline & 5 & 0.0011 & 0.638 & 99.00 \\
\hline & 10 & 0.0017 & 0.986 & 84.58 \\
\hline & 15 & 0.0013 & 0.754 & 94.12 \\
\hline & 20 & 0.0015 & 0.870 & 87.80 \\
\hline \multirow{5}{*}{ Stems } & Blank & 0.0445 & 25.830 & - \\
\hline & 5 & 0.0046 & 4.817 & 86.21 \\
\hline & 10 & 0.0040 & 2.318 & 89.88 \\
\hline & 15 & 0.0001 & 0.116 & 99.79 \\
\hline & 20 & 0.0035 & 2.031 & 92.13 \\
\hline \multirow{5}{*}{ Flowers } & Blank & 0.0350 & 20.310 & - \\
\hline & 5 & 0.0083 & 4.817 & 76.28 \\
\hline & 10 & 0.0002 & 0.116 & 99.42 \\
\hline & 15 & 0.0005 & 0.290 & 98.57 \\
\hline & 20 & 0.0040 & 2.321 & 88.57 \\
\hline \multirow{5}{*}{ Tubers } & Blank & 0.0849 & 49.281 & - \\
\hline & 5 & 0.0089 & 5.166 & 89.51 \\
\hline & 10 & 0.0003 & 0.170 & 99.64 \\
\hline & 15 & 0.0120 & 6.965 & 88.86 \\
\hline & 20 & 0.0110 & 6.385 & 87.04 \\
\hline
\end{tabular}
INHIBITOR IN $1 \mathrm{~N}$ HCl MEDIUM

$\mathrm{GSL}=$ Gloriosa superba Linn.
The pretreated specimens were fully and separately immersed in $100 \mathrm{~mL}$ of $1 \mathrm{~N} \mathrm{HCl}$ at room temperature. The inhibition efficiency of Gloriosa superba Linn. extract on mild steel as a function of time was presented in Table-2. Hence more adsorption takes place on the mild steel surface, the inhibition efficiency increases with an increase in immersion time and inhibitive properties of the Gloriosa superba Linn. extract are fairly good for studied situation.

TABLE-2

\begin{tabular}{|c|c|c|c|c|c|c|c|}
\hline \multirow{2}{*}{$\begin{array}{c}\text { Parts of } \\
\text { GSL } \\
\text { plant }\end{array}$} & \multirow{2}{*}{$\begin{array}{l}\text { Conc. } \\
\text { of the } \\
\text { extract } \\
\text { (ppm) }\end{array}$} & \multicolumn{6}{|c|}{ Inhibition efficiency (\%) } \\
\hline & & $1 \mathrm{~h}$ & $3 \mathrm{~h}$ & $5 \mathrm{~h}$ & $7 \mathrm{~h}$ & $9 \mathrm{~h}$ & $12 \mathrm{~h}$ \\
\hline \multirow{5}{*}{ Leaves } & Blank & - & - & - & - & - & - \\
\hline & 5 & 68.10 & 71.53 & 66.76 & 64.39 & 54.32 & 45.56 \\
\hline & 10 & 78.10 & 80.25 & 78.54 & 76.76 & 60.12 & 68.72 \\
\hline & 15 & 87.50 & 89.99 & 86.16 & 87.96 & 82.49 & 86.95 \\
\hline & 20 & 90.2 & 92.16 & 93.15 & 90.37 & 91.30 & 94.10 \\
\hline \multirow{4}{*}{ Stem } & 5 & 70.31 & 74.90 & 80.33 & 86.16 & 85.78 & 90.12 \\
\hline & 10 & 75.08 & 86.59 & 87.88 & 87.72 & 86.88 & 94.78 \\
\hline & 15 & 78.85 & 88.90 & 89.19 & 89.15 & 87.22 & 96.91 \\
\hline & 20 & 84.93 & 92.03 & 93.05 & 94.09 & 90.78 & 95.01 \\
\hline \multirow{4}{*}{ Flowers } & 5 & 72.81 & 78.90 & 76.14 & 74.21 & 83.89 & 78.90 \\
\hline & 10 & 75.95 & 80.16 & 85.33 & 76.78 & 87.28 & 89.13 \\
\hline & 15 & 78.84 & 84.56 & 87.60 & 82.59 & 87.99 & 92.98 \\
\hline & 20 & 93.21 & 91.89 & 92.69 & 90.17 & 93.89 & 94.16 \\
\hline \multirow{4}{*}{ Tubers } & 5 & 78.90 & 74.93 & 80.23 & 83.78 & 86.87 & 89.21 \\
\hline & 10 & 86.98 & 80.54 & 85.33 & 84.98 & 88.96 & 90.56 \\
\hline & 15 & 87.98 & 83.44 & 86.59 & 88.98 & 89.18 & 92.21 \\
\hline & 20 & 92.62 & 90.34 & 94.25 & 92.09 & 91.54 & 94.60 \\
\hline
\end{tabular}

INHIBITION EFFICIENCY AT VARIOUS IMMERSION TIMES

FTIR Measurement: The FTIR spectroscopy is not capable to firm exactly the main structure of the extract, but evident what it's the more abundant chemical composites. FTIR spectra of the Gloriosa superba Linn plants of various parts like leaves, stems, tubers and flowers extract was shown in Fig. 1. For Gloriosa superba Linn, which contain bands (leaves, stems flowers and tubers) corresponding 3301.30, 3272.56, 3396.15, $3170.23 \mathrm{~cm}^{-1}$ can be assigned to hydroxyl group respectively. Strong peak at $1645.55 \mathrm{~cm}^{-1}$ correspond to carbonyl group. The presence of aliphatic stretching of C-H is shown at frequency 2921.34, 2923.07, 2923.33, $2967.78 \mathrm{~cm}^{-1}$ (leaves, stems, flowers and tuber) respectively. The absorbance at 1597.46 and $1648.18 \mathrm{~cm}^{-1}$ as well as several band between 1328.34 to $1040.72 \mathrm{~cm}^{-1}$ that indicates the presence of aromatic ring.

Potentiodynamic polarization studies: The Tafel parameters for mild steel in the absence and presence of an inhibitor concentration of Gloriosa superba Linn. extract in $1 \mathrm{~N} \mathrm{HCl}$ are presented in Table- 3 and its polarization curve are shown in Fig. 2. Fig. 2 showed that the addition of Gloriosa superba Linn. inhibitor did not affect the values of $\mathrm{E}_{\text {corr }}$ large extent but both anodic dissolution of mild steel and cathodic reduction reaction was observed, indicating that the composite could be classified as mixed type inhibitor. It was observed from the table that the corrosion current density $\left(\mathrm{I}_{\text {corr }}\right)$ decreases with increasing inhibitors concentration. The maximum inhibition efficiency detected at higher inhibitor concentration shows that more inhibitor molecules are adsorbed on the metal surface, 


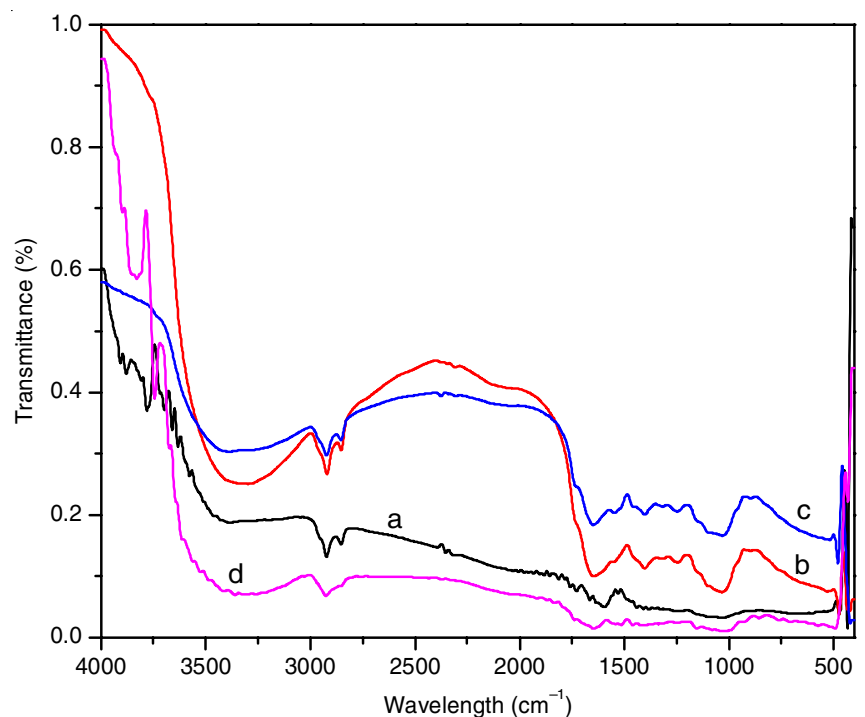

Fig. 1. FTIR spectra of Gloriosa superba Linn. (a) leaves, (b) barks, (c) fruits and (d) tubers extracts

which provides more surface coverage for the active sites of mild steel where direct attack occurs and migrates the corrosion
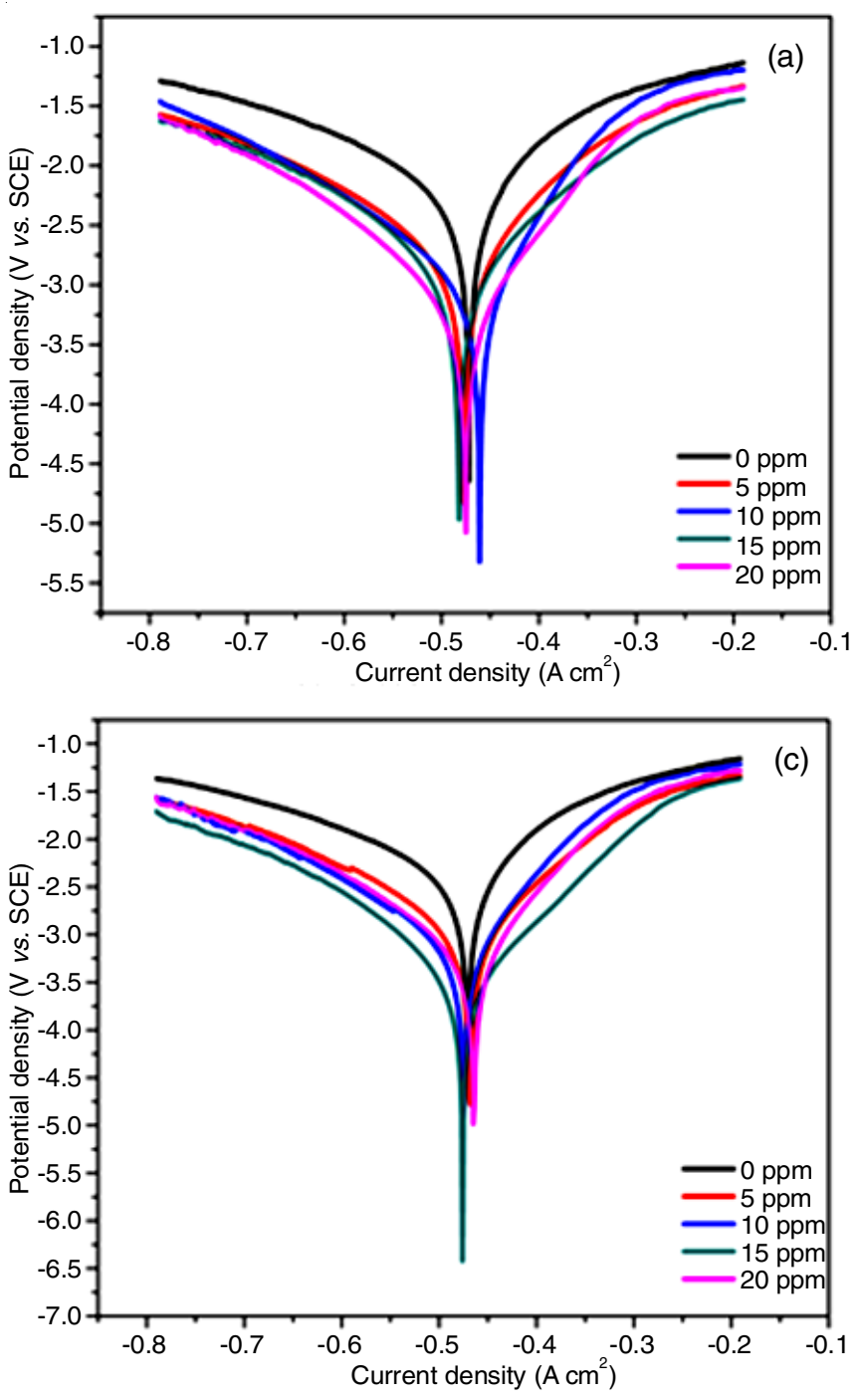

attack. From these findings, the maximum inhibition efficiency of $99.80 \%$ was observed for Gloriosa superba Linn. stems extract at $15 \mathrm{ppm}$.

Electrochemical impedance studies (EIS): Impedance spectroscopy is one of the most simple and consistent techniques and also used to study the characterization of electrode (surface) behaviour in $1 \mathrm{~N} \mathrm{HCl}$ solution in the absence and presence of the plants extracts [49-52]. Fig. 3 shows the Nyquist plots of various parts of Gloriosa superba Linn plants like leaves, stems, tubers and flowers at various concentrations. The different corrosion parameters derived from EIS measurement are presented as Table-4. The impedance spectra showed a single semicircle and as the concentration of inhibitor increases diameter of the semicircle increases, indicating that the charge-transfer process mainly controls the corrosion of mild steel surface and retards the electron transfer reaction and form strong protective film. It was noted from the table that the significant increase in $\mathrm{R}_{\mathrm{ct}}$ and decrease in the $\mathrm{C}_{\mathrm{dl}}$ values with increase in concentration of inhibitor indicated the increased inhibition efficiency of the inhibitor [53-56].

Phytochemical screening method: Phytochemical screening of the aerial parts of plant's powder (aqueous) extract
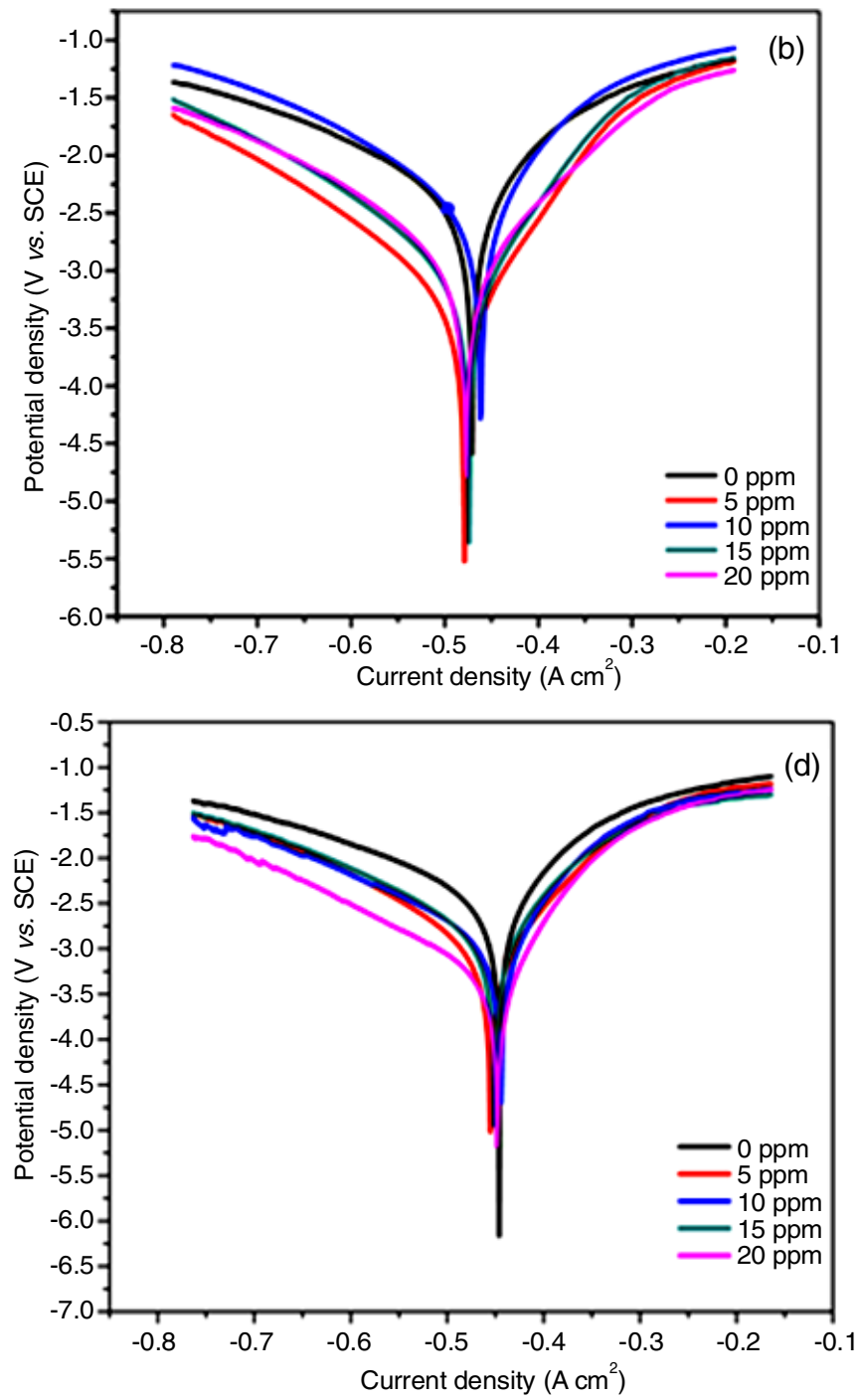

Fig. 2. Potentiodynamic polarization (Tafel) curves for mild steel in $1 \mathrm{~N} \mathrm{HCl}$ solution in the absence and presence of different concentration of Gloriosa superba Linn. extracts of (a) leaves (b) barks (c) fruits (d) tubers 


\begin{tabular}{|c|c|c|c|c|c|c|}
\hline \multicolumn{7}{|c|}{$\begin{array}{c}\text { TABLE-3 } \\
\text { POLARIZATION MEASUREMENT AND CALCULATED VALUES OF IE (\%) AT } \\
\text { DIFFERENT CONCENTRATION OF Gloriosa superba Linn. EXTRACT }\end{array}$} \\
\hline $\begin{array}{l}\text { Parts of Gloriosa } \\
\text { superba Linn. plant }\end{array}$ & Conc. (ppm) & $\mathrm{E}_{\text {corr }}(\mathrm{mV} / \mathrm{SCE})$ & $\mathrm{I}_{\text {corr }}\left(\mathrm{mA} / \mathrm{cm}^{2}\right)$ & $\mathrm{b}_{\mathrm{c}}(\mathrm{mV} / \mathrm{dec})$. & $\mathrm{b}_{\mathrm{a}}(\mathrm{mV} / \mathrm{dec})$. & IE (\%) \\
\hline \multirow{5}{*}{ Leaves } & Blank & -0.471 & $4.706 \times 10^{-3}$ & 208.85 & 153.42 & $*$ \\
\hline & 5 & -0.468 & $1.067 \times 10^{-3}$ & 160.20 & 115.54 & 99.77 \\
\hline & 10 & -0.475 & $7.255 \times 10^{-4}$ & 165.34 & 90.17 & 84.58 \\
\hline & 15 & -0.476 & $3.237 \times 10^{-4}$ & 131.50 & 100.19 & 93.12 \\
\hline & 20 & -0.465 & $6.079 \times 10^{-4}$ & 146.04 & 90.48 & 87.08 \\
\hline \multirow{5}{*}{ Flowers } & Blank & -0.471 & $4.706 \times 10^{-3}$ & 208.85 & 153.42 & $*$ \\
\hline & 5 & -0.455 & $8.821 \times 10^{-4}$ & 155.71 & 93.51 & 76.00 \\
\hline & 10 & -0.444 & $1.394 \times 10^{-3}$ & 191.57 & 104.42 & 99.63 \\
\hline & 15 & -0.451 & $1.516 \times 10^{-3}$ & 174.97 & 116.42 & 99.59 \\
\hline & 20 & -0.448 & $5.559 \times 10^{-4}$ & 188.46 & 87.366 & 85.29 \\
\hline \multirow{5}{*}{ Stems } & Blank & -0.471 & $4.706 \times 10^{-3}$ & 208.85 & 153.42 & $*$ \\
\hline & 5 & -0.477 & $8.990 \times 10^{-4}$ & 166.66 & 86.26 & 86.00 \\
\hline & 10 & -0.461 & $1.642 \times 10^{-3}$ & 179.53 & 129.33 & 99.79 \\
\hline & 15 & -0.482 & $1.235 \times 10^{-3}$ & 160.79 & 138.77 & 99.80 \\
\hline & 20 & -0.475 & $5.827 \times 10^{-4}$ & 143.18 & 94.62 & 91.01 \\
\hline \multirow{5}{*}{ Tubers } & Blank & -0.471 & $4.706 \times 10^{-3}$ & 208.85 & 153.42 & $*$ \\
\hline & 5 & -0.479 & $4.501 \times 10^{-4}$ & 153.61 & 84.14 & 90.44 \\
\hline & 10 & -0.462 & $3.672 \times 10^{-3}$ & 178.99 & 128.65 & 99.21 \\
\hline & 15 & -0.474 & $7.388 \times 10^{-4}$ & 156.96 & 87.98 & 84.50 \\
\hline & 20 & -0.477 & $1.087 \times 10^{-3}$ & 163.11 & 122.91 & 99.00 \\
\hline
\end{tabular}
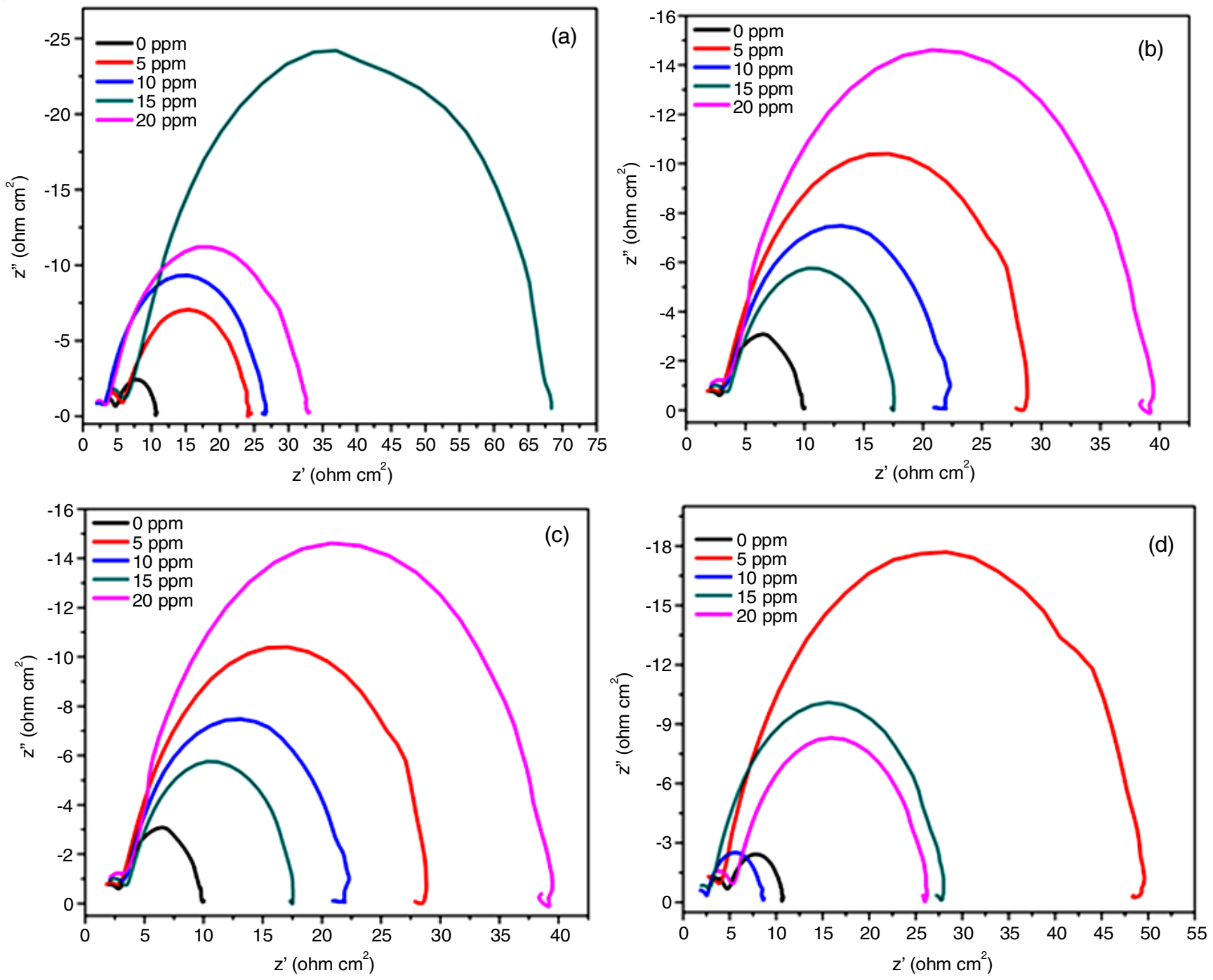

Fig. 3. Nyquist plots for mild steel in $1 \mathrm{~N} \mathrm{HCl}$ acid solution without and with presence of different concentration of Gloriosa superba Linn. extract of (a) leaves (b) bark (c) fruits (d) tubers 


\begin{tabular}{|c|c|c|c|c|}
\hline \multicolumn{5}{|c|}{$\begin{array}{c}\text { TABLE-4 } \\
\text { EIS PARAMETER FOR MILD STEEL IN } 1 \text { N HCI ACID } \\
\text { SOLUTION WITHOUT AND WITH THE VARIED } \\
\text { CONCENTRATION OF PLANT EXTRACT }\end{array}$} \\
\hline $\begin{array}{c}\text { Parts of } \\
\text { GSL plant }\end{array}$ & $\begin{array}{l}\text { Conc. } \\
\text { (ppm) }\end{array}$ & $\begin{array}{c}\mathrm{R}_{\mathrm{ct}}(\mathrm{ohm} \\
\left.\mathrm{cm}^{2}\right)\end{array}$ & $\begin{array}{c}\mathrm{C}_{\mathrm{dl}} \\
\left(\mu \mathrm{F} / \mathrm{cm}^{2}\right)\end{array}$ & $\operatorname{IE}(\%)$ \\
\hline \multirow{5}{*}{ Leaves } & Blank & 10.622 & 6.2385 & $*$ \\
\hline & 5 & 23.091 & $9.72 \times 10^{-4}$ & 55.96 \\
\hline & 10 & 25.416 & $6.57 \times 10^{-4}$ & 59.99 \\
\hline & 15 & 66.849 & $9.82 \times 10^{-5}$ & 84.78 \\
\hline & 20 & 32.213 & $4.43 \times 10^{-4}$ & 68.43 \\
\hline \multirow{5}{*}{ Flowers } & Blank & 10.622 & 6.2385 & $*$ \\
\hline & 5 & 29.125 & $5.29 \times 10^{-4}$ & 70.36 \\
\hline & 10 & 22.899 & $9.35 \times 10^{-4}$ & 62.30 \\
\hline & 15 & 14.960 & 1.8530 & 42.29 \\
\hline & 20 & 38.800 & $2.78 \times 10^{-4}$ & 77.75 \\
\hline \multirow{5}{*}{ Stems } & Blank & 10.622 & 6.2385 & $*$ \\
\hline & 5 & 18.093 & 1.6131 & 63.88 \\
\hline & 10 & 25.926 & $7.29 \times 10^{-4}$ & 74.79 \\
\hline & 15 & 28.411 & $7.51 \times 10^{-4}$ & 77.00 \\
\hline & 20 & 40.866 & $2.85 \times 10^{-4}$ & 84.01 \\
\hline \multirow{5}{*}{ Tubers } & Blank & 10.622 & 6.2385 & $*$ \\
\hline & 5 & 49.722 & $1.81 \times 10^{-4}$ & 78.63 \\
\hline & 10 & 17.856 & 3.5388 & 40.51 \\
\hline & 15 & 28.342 & $5.67 \times 10^{-4}$ & 62.52 \\
\hline & 20 & 25.597 & $7.51 \times 10^{-4}$ & 58.50 \\
\hline
\end{tabular}

was tested in order to find the presence of various chemical constituent included alkaloids, carbohydrates, proteins, saponins, triterpenoids and tannins and the outcomes are listed in Table-5.

Surface examination studies: The morphologies of the mild steel immersed in blank $1 \mathrm{~N} \mathrm{HCl}$ and with optimum concentration of the inhibitor for $24 \mathrm{~h}$ was analyzed by scanning electron microscopy (SEM) and are shown in Fig. 4(a-e). SEM images (Fig. 4b-e) revealed that the plants extract which was adsorbed on the metal surface decreased the metal surface from corrosion attack. From this it was clearly shown that Gloriosa superba Linn. plants extract act as an excellent green inhibitor in $1 \mathrm{~N} \mathrm{HCl}$ medium.

\begin{tabular}{lllll}
\multicolumn{5}{c}{ TABLE-5 } \\
\multicolumn{5}{c}{ PHYTOCHEMICAL SCREENING TEST OF } \\
\hline $\begin{array}{c}\text { Phytochemical } \\
\text { test }\end{array}$ & Leaves & Flowers & Tubers & Stem \\
\hline Alkaloids & Presence & Presence & Presence & Presence \\
Carbohydrates & Presence & Presence & Absence & Presence \\
Proteins & Presence & Presence & Presence & Absence \\
Saponins & Absence & Absence & Presence & Presence \\
Thiols & Presence & Absence & Absence & Absence \\
Tannins & Absence & Absence & Presence & Absence \\
Flavanoids & Absence & Presence & Presence & Presence \\
Phenol & Absence & Presence & Presence & Absence \\
Glycosides & Absence & Presence & Presence & Presence \\
\hline
\end{tabular}

Influence of temperature: To assess the effect of temperature on corrosion and corrosion inhibition process, mass loss methods were performed at different temperature (303-323 $\mathrm{K})$ in the absence and presence of various concentration of the inhibitor during $3 \mathrm{~h}$ of immersion. The results are given in Table-6.

Adsorption studies: Adsorption studies are used to investigate the mode of adsorption and its characteristics as an inhibitor on the mild steel surface. In present study the Temkin adsorption isotherm is investigated. The straight line (Fig. 5) clearly indicated that the inhibitor obey Temkin adsorption isotherm satisfactorily.

Mechanism of inhibition: The possible mechanism of inhibition can be described on the center of adsorption method and the structure of the components present in the Gloriosa superba Linn. plant extracts. The leading constituent of Gloriosa superba Linn. plant extract is colchicine and colchides whose structures are given in Figs. 6 and 7 having multiple bonds though which they get adsorbed on the metal surface. The compounds have to block the vigorous corrosion positions on the mild steel surface and hence the adsorption occurs by the bonding of the free electron of inhibitor with the metal. Phytochemical analysis showed the presence of glycosides, flavonoids, saponins, steroids, tannins and alkaloids. Above organic
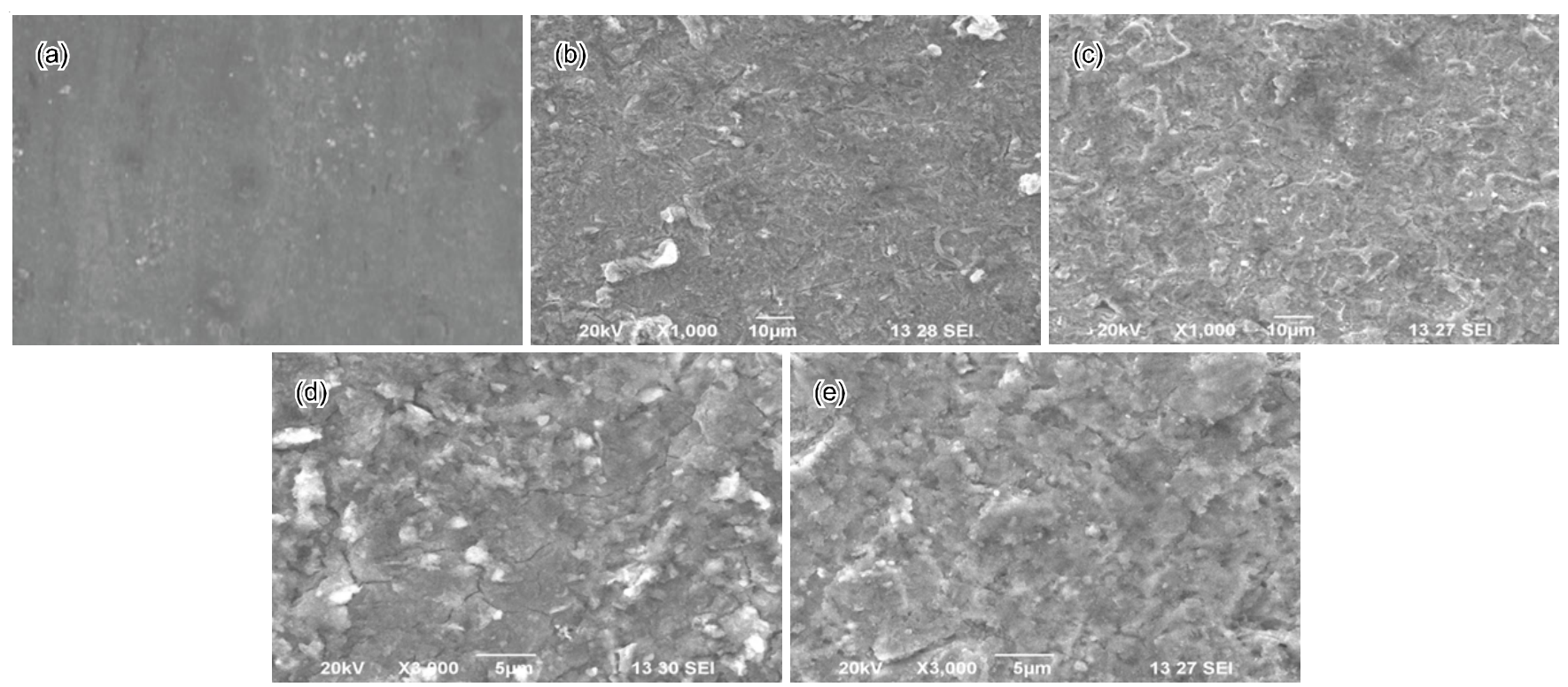

Fig. 4. SEM images of the surface of mild steel immersed in $1 \mathrm{~N} \mathrm{HCl}$ after one day at room temperature (a) after immersion without inhibitor and with immersed optimum concentration of Gloriosa superba Linn. plant extracts from (b) leaves, (c) barks (d) fruits and (e) seeds 



Fig. 5. Temkin adsorption isotherm plot for mild steel in $1 \mathrm{~N} \mathrm{HCl}$ containing different concentration of Gloriosa superba Linn plant extracts (a) leaves (b) barks (c) fruits and (d) tubers

\begin{tabular}{|c|c|c|c|c|}
\hline \multicolumn{5}{|c|}{$\begin{array}{c}\text { TABLE-6 } \\
\text { PERCENTAGE INHIBITION EFFICIENCY OF Gloriosa superba } \\
\text { Linn. (GSL) PLANTS AT VARIOUS TEMPERATURES }\end{array}$} \\
\hline \multirow{2}{*}{$\begin{array}{c}\text { Parts of } \\
\text { GSL plant }\end{array}$} & \multirow{2}{*}{$\begin{array}{c}\text { Conc. of } \\
\text { extract (ppm) }\end{array}$} & \multicolumn{3}{|c|}{$\operatorname{IE}(\%)$} \\
\hline & & $303 \mathrm{~K}$ & $313 \mathrm{~K}$ & $323 \mathrm{~K}$ \\
\hline \multirow{5}{*}{ Leaves } & Blank & - & - & - \\
\hline & 5 & 44.10 & 49.12 & 66.76 \\
\hline & 10 & 57.60 & 57.67 & 72.54 \\
\hline & 15 & 62.28 & 63.95 & 80.16 \\
\hline & 20 & 76.65 & 82.12 & 93.15 \\
\hline \multirow{4}{*}{ Stem } & 5 & 66.66 & 65.50 & 64.55 \\
\hline & 10 & 71.11 & 69.40 & 68.54 \\
\hline & 15 & 81.48 & 75.97 & 74.76 \\
\hline & 20 & 82.22 & 79.05 & 77.79 \\
\hline \multirow{4}{*}{ Flowers } & 5 & 44.35 & 49.85 & 51.67 \\
\hline & 10 & 48.69 & 53.97 & 59.59 \\
\hline & 15 & 54.55 & 57.64 & 70.29 \\
\hline & 20 & 68.76 & 71.48 & 75.65 \\
\hline \multirow{4}{*}{ Tubers } & 5 & 47.40 & 52.15 & 56.81 \\
\hline & 10 & 50.37 & 59.13 & 64.37 \\
\hline & 15 & 60.01 & 68.17 & 68.36 \\
\hline & 20 & 71.10 & 74.70 & 79.03 \\
\hline
\end{tabular}<smiles>COc1cc2c(c(OC)c1OC)-c1ccc(OC)c(=O)cc1[C@@H](NC(C)=O)CC2</smiles>

Fig. 6. Chemical structure of colchicine

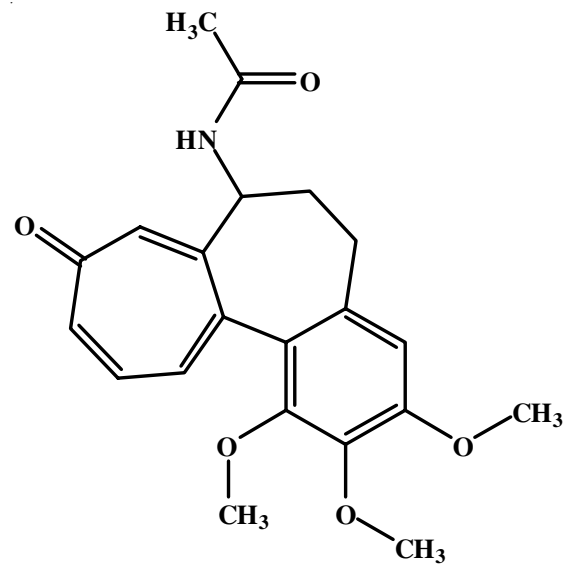

Fig. 7. Chemical structure of colchides

fragments grows adsorbed on the metal surface developing a protecting film and difference in inhibitory properties of inhibitor is closely related to the difference in molecular structure [57-59].

\section{Conclusion}

The medicinal plants of Gloriosa superba Linn. extract can acts as an excellent eco-friendly green inhibitor, cost effective and easily available for the corrosion of mild steel in $1 \mathrm{~N} \mathrm{HCl}$. The extracts of Gloriosa superba Linn. plants showed maximum efficiency of $99.80 \%$ stem at the optimum concentration of $15 \mathrm{ppm}$ for one day immersion time at room temperature. The best correlations among the experimental outcomes showed in weight loss method have good agreement with the electrochemical methods. The Gloriosa superba Linn. plants extracts act as a mixed type inhibitor; they suppressed both cathodic and anodic process. The adsorbed film over the 
mild steel surface has been confirmed by SEM analysis. The adsorption of Gloriosa superba Linn. plants extract at mild steel - acid solution interface followed the Temkin adsorption isotherm.

\section{REFERENCES}

1. A.P. Srikanth, S. Nanjundan and N. Rajendran, Prog. Org. Coat., 60, 320 (2007); https://doi.org/10.1016/j.porgcoat.2007.08.001

2. A.A. El-Hosary, R.M. Saleh and A.M. Shams El-Din, Corros. Sci., 12, 897 (1972); https://doi.org/10.1016/S0010-938X(72)80098-2.

3. M. Shyamala and P.K. Kasthuri, Int. J. Corros., Article ID 129647 (2011); https://doi.org/10.1155/2011/129647.

4. M. Karuppusamy, P.R. Sivakumar, S. Perumal, A. Elangovan and A.P. Srikanth, J. Environ. Nano., 4, 09 (2015); https://doi.org/10.13074/jent.2015.06.152143.

5. A.P. Srikanth, V. Raman, S. Tamilselvi, S. Nanjundan and N. Rajendran, Anti-corrosion Methods Mater, 55, 3 (2008); https://doi.org/10.1108/00035590810842762.

6. P.R. Sivakumar and A.P. Srikanth, Int. J. Phys. Appl. Sci., 3, 10 (2016).

7. C.A. Loto and A.I. Mohammed, Corros. Prev. Control, 47, 5056 (2000).

8. A.P. Srikanth, T.G. Sunitha, V. Raman, S. Nanjundan and N. Rajendran, Mater. Chem. Phys., 103, 241 (2007); https://doi.org/10.1016/j.matchemphys.2007.02.021.

9. A.Y. El-Etre, Corros. Sci., 45, 2485 (2003); https://doi.org/10.1016/S0010-938X(03)00066-0.

10. J. Bruneton, Tec \& Doc-Edition, Medicinales Internationales, Paris; France, edn 4 (2009).

11. P.R. Sivakumar and A.P. Srikanth, Int. J. Eng. Sci. Comport., 6, 2744 (2016).

12. K. Vishalakshi, P.R. Sivakumar and A.P. Srikanth, Int. Org. Sci. Res. J. Appl. Chem., 9, 50 (2016).

13. M. Ajmal, A.S. Mideen and M.A. Quraishi, Corros. Sci., 36, 79 (1994); https://doi.org/10.1016/0010-938X(94)90110-4.

14. A.P. Srikanth, T.G. Sunitha, S. Nanjundan and N. Rajendran, Prog. Org. Coat., 56, 120 (2006); https://doi.org/10.1016/j.porgcoat.2006.01.008

15. S.A. Verma and M.N. Mehta, Soc. Adv. Electrochem. Sci. Technol., 32, 89 (1997).

16. I.B. Obot, S.A. Umoren and N.O. Obi-Egbedi, J. Mater Environ. Sci., 2, 60 (2011)

17. H. Al-Sehaibani, Materialwiss. Werkstofftech., 31, 1060 (2000); https://doi.org/10.1002/1521-4052(200012)31:12<1060::AID-MAWE 1060>3.0.CO;2-K.

18. P.B. Raja, M. Ismail, S. Ghoreishiamiri, J. Mirza, M.C. Ismail, S. Kakooei and A.A. Rahim, Chem. Eng. Commun., 203, 1145 (2016); https://doi.org/10.1080/00986445.2016.1172485.

19. P.R. Sivakumar, M. Karuppusamy, S. Perumal, A. Elangovan and A.P. Srikanth, J. Environ. Nano., 4, 31 (2015); https://doi.org/10.13074/jent.2015.06.152144.

20. G.D. Davis, DACCO SCI Inc. Columbia Md; USA (2000)

21. O.K. Abiola, J. Corros. Sci. Eng., 5, 10 (2006).

22. A.O. James and E.O. Ekpe, Int. J. Pure Appl. Chem., 35, 10 (2002).

23. M. Lebrini, F. Robert and C. Roos, Int. J. Electrochem. Sci., 6, 847 (2011).

24. P.R. Sivakumar, K. Vishalakshi and A.P. Srikanth, J. Appl. Chem., 5, 1080 (2016).

25. E.E. Ebenso, N.O. Eddy and A.O. Odiongenyi, Afr. J. Pure Appl. Chem., 2, 107 (2008).

26. I.M. Mejeha, A.A. Uroh, K.B. Okeoma and G.A. Alozie, Afr. J. Pure Appl. Chem., 4, 158 (2010).

27. P.R. Sivakumar, M. Karuppusamy, K. Vishalakshi and A.P. Srikanth, Der Pharma Chem., 8, 74 (2016).

28. A.Y. El-Etre, M. Abdallah and Z.E. El-Tantawy, Corros. Sci., 47, 385 (2005); https://doi.org/10.1016/j.corsci.2004.06.006.
29. E.E. Oguzie, Mater. Chem. Phys., 99, 441 (2006); https://doi.org/10.1016/j.matchemphys.2005.11.018.

30. G. Gunasekaran and L.R. Chauhan, Electrochim. Acta, 49, 4387 (2004); https://doi.org/10.1016/j.electacta.2004.04.030.

31. K.O. Orubite and N.C. Oforka, Mater. Lett., 58, 1768 (2004); https://doi.org/10.1016/j.matlet.2003.11.030.

32. Y. Li, P. Zhao, Q. Liang and B. Hou, Appl. Surf. Sci., 252, 1245 (2005); https://doi.org/10.1016/j.apsusc.2005.02.094.

33. M.A. Quraish and D.K. Yadav, Corrosion and its Control by Some Green Inhibitor, In: Proceedings of the 14th National Congress on Corrosion Control, Hotel Green Park, Hyderabad, India, 18-20, September (2008).

34. H.O. Edeoga, D.E. Okwu and B.O. Mbaebie, Afr. J. Biotechnol., 4, 685 (2005); https://doi.org/10.5897/AJB2005.000-3127.

35. R. Ade and M.K. Rai, Biodiversitas, 10, 210 (2009); https://doi.org/10.13057/biodiv/d100409.

36. C. Alagesaboopathi, J. Microbiol., 5, 617 (2011); https://doi.org/10.5897/AJMR10.448.

37. S. Hemaiswarya, R. Raja, C. Anbazhagan and V. Thiagarajan, Pak. J. Bot., 41, 293 (2009).

38. R. Rehanabanu and N. Nagarajan, Int. Res. J. Pharm., 2, 139 (2011).

39. A. Mathur, S.K. Verma, S.K. Singh, D. Mathur, G.B.K.S. Prasad and V.K. Dua, Rec. Res. Sci. Technol., 3, 40 (2011)

40. C.P. Kala, Int. J. Med. Arom. Plants., 1, 153 (2011).

41. H. Khan, M.A. Khan and I. Hussan, J. Enzyme Inhib. Med. Chem., 22, 722 (2007); https://doi.org/10.1080/14756360601164853.

42. U.C. Srivastava and V. Chandra, J. Res. Indian Med., 10, 92 (1977).

43. R. Chitra and K. Rajamani, Acad. J. Plant Sci., 2, 39 (2009).

44. A. Lalitha, S. Ramesh and S. Rajeswari, Electrochim. Acta, 51, 47 (2005); https://doi.org/10.1016/j.electacta.2005.04.003.

45. D. Kavithamani, M. Umadevi and S. Geetha, Indian J. Res. Pharm. Biotech., 1, 554 (2013).

46. W. Li, Q. He, S. Zhang, C. Pei and B.J. Hou, Appl. Electrochem., 38, 289 (2008); https://doi.org/10.1007/s10800-007-9437-7.

47. F.R. Selvarani, S. Santhanalakshmi, J.W. Sahayaraj, A.J. Amalraj and S.S. Rajendran, Bull. Electrochem., 20, 561 (2004).

48. S. Rajendran, S.M. Reenkala, N. Anthony and R. Ramaraj, Corros. Sci., 44, 2243 (2002); https://doi.org/10.1016/S0010-938X(02)00052-5.

49. W.R. Fawcett, Z. Kovacova, A.J. Motheo and C.A. Foss Jr., J. Electroanal. Chem., 326, 91 (1992); https://doi.org/10.1016/0022-0728(92)80505-X.

50. M. Lebrini, F. Robert and C. Roos, Int. J. Electrochem. Sci., 5, 1698 (2010).

51. R. Saratha and V.G. Vasudha, E-J. Chem., 7, 677 (2010); https://doi.org/10.1155/2010/162375.

52. A.M. Badiea and K.N. Mohana, J. Mater. Eng. Perform., 18, 1264 (2009); https://doi.org/10.1007/s11665-009-9378-x.

53. P.B. Raja, A.A. Rahim, H. Osman and K. Awang, Acta Physico-Chimica Sinica, 26, 2171 (2010); https://doi.org/10.3866/PKU.WHXB20100646.

54. A. Sarmila, A.A. Prema and P.A. Sahayaraj, Rasayan J. Chem., 3, 74 (2010).

55. M.A. Velazquez-Gonzalez, J.G. Gonzalez-Rodriguez, M.G. ValladaresCisneros and I.A. Hermoso-Diaz, Am. J. Anal. Chem., 5, 55 (2014); https://doi.org/10.4236/ajac.2014.52009.

56. E.A. Noor, J. Appl. Electrochem., 39, 1465 (2009); https://doi.org/10.1007/s10800-009-9826-1.

57. N.S. Patel, S. Jauhariand, G.N. Mehta, S.S. Al-Deyab, I. Warad and B. Hammouti, Int. J. Electrochem. Sci., 8, 2635 (2013).

58. N.R. Nair and I.K. Shashi Sharma, Rasayan J. Chem., 3, 783 (2010).

59. A.P. Srikanth, A. Lavanya, S. Nanjundan and N. Rajendran, Appl. Surf. Sci., 253, 1810 (2006); https://doi.org/10.1016/j.apsusc.2006.03.029. 